\title{
Report to Congress
}

\section{Equity of Commercial Low-Level Radioactive Waste Disposal Fees}

\section{U.S. Department of Energy}

Office of Environmental Management Washington, DC 20585

EMTREUTION OF TME DOCUMENT IS UNLMTTEO February 1998 MASTER 


\section{DISCLAIMER}

Portions of this document may be illegible electronic image products. Images are produced from the best available original document. 


\section{CONTENTS}

1. INTRODUCTION 1

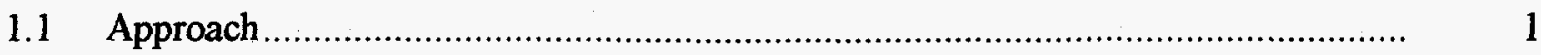

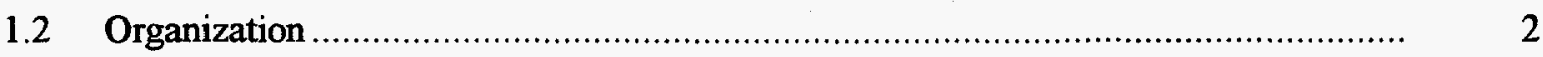

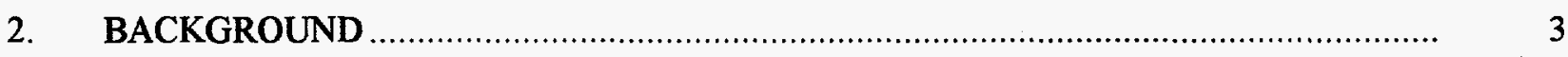

$2.1 \quad$ History and Status of Compact Development ...................................................

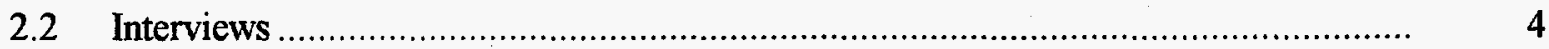

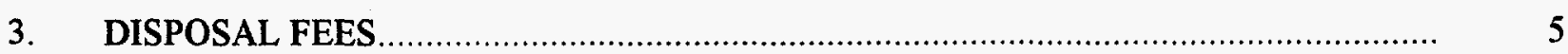

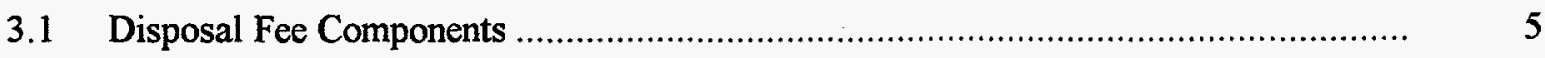



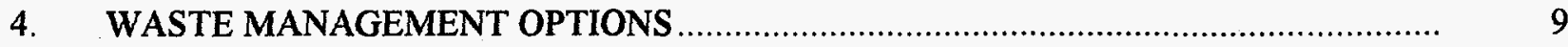

$4.1 \quad$ LLW Management Options ....................................................................... 10

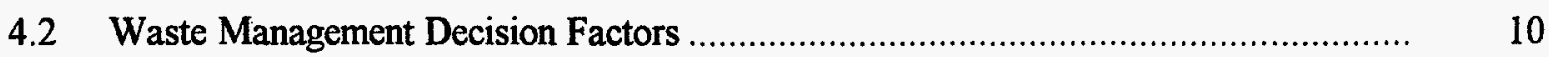

4.3 Conditions that Complicate LLW Management Choices................................. 10

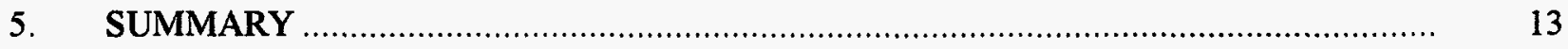

APPENDIX - Low-Level Waste Disposal Evaluation Questionnaire .................................. 14

\section{TABLES}

1. Taxes and fees applicable to active and proposed LLW disposal facilities. ........................ 6

2. Comparison of disposal costs for a hypothetical LLW shipment. ................................ 8

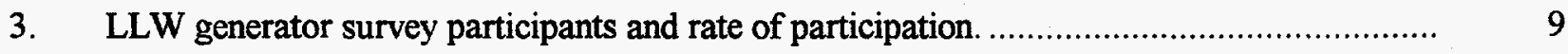

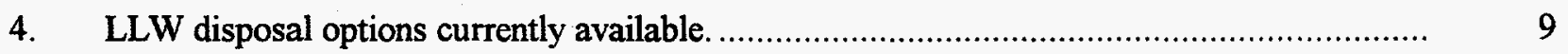

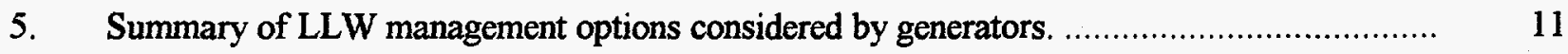

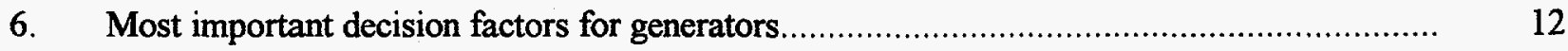




\section{Equity of Commercial \\ Low-Level Radioactive Waste Disposal Fees}

\section{INTRODUCTION}

In the Report accompanying the Fiscal Year 1997 Senate Energy and Water Development Appropriations Bill, the Senate Appropriations Committee directed the Department of Energy (DOE) to prepare a study of the costs of operating a low-level radioactive waste (LLW) disposal facility such as the one at Barnwell, South Carolina, and to determine whether LLW generators are paying equitable disposal fees. Specifically, the Report states:

Due to a limited competitive market and the extensive use by the Department of Defense, the Committee directs the Department's national low-level radioactive management programs shall conduct a study of the costs of operating a low-level radioactive waste disposal facility such as the commercial low-level radioactive waste disposal facility at Barnwell, SC. This study is to ensure that the Department of Defense, the Veterans' Administration, and any other waste generators are paying equitable disposal fees.

The disposal costs of four facilities are reviewed in this report, two operating facilities and two planned facilities. The operating facilities are located at Barnwell, South Carolina, and Richland, Washington. They are operated by Chem-Nuclear, LLC, (Chem-Nuclear), and US Ecology, Inc., (US Ecology), respectively. The planned facilities are expected to be built at Ward Valley, California, and Sierra Blanca, Texas. They will be operated by US Ecology and the State of Texas, respectively.

A fifth facility is also available for LLW disposal. This unique facility is located at Clive, Utah, and is operated by Envirocare of Utah (Envirocare). This facility is unique due to the types of waste it receives, how the waste is shipped, and how it disposes of the waste. While the other four facilities are designed to provide disposal for the full range of Class A, B, and C LLW, the Envirocare facility is licensed to receive only a portion of low-activity, Class A wastes. In addition, the facility is licensed to receive large volume, bulk shipments of naturally occurring radioactive material (NORM), mill tailings, and some mixed wastes. Most of the waste that Envirocare receives is shipped in bulk-type rail cars instead of drums. Disposal is made in above-grade mounds covered with rip-rap covers rather than in trenches or concrete vaults. Because of these significant differences, the Envirocare facility is not comparable to the other facilities reviewed in this report and is not included in the disposal fee comparison.

This report found that disposal fees vary significantly among facilities for a variety of reasons. However, the information suggests that at each disposal facility, LLW generators pay equitable disposal fees.

\subsection{Approach}

The approach to the study involved the following major steps: 
- Interview operators of current disposal facilities

- Interview representatives of state regulatory agencies

- $\quad$ Prepare and conduct a small survey of LLW generators to gain a sense of the factors that influence their waste disposal decisions

- Determine disposal fees for several operating and proposed LLW disposal facilities.

Telephone interviews and personal discussions were conducted with a representative of Chem-Nuclear, US Ecology, and Envirocare. These interviews and discussions were a means of understanding how disposal rates are determined. Telephone interviews were also conducted with representatives of four state regulatory agencies to obtain information about current surcharges, taxes, and fees that are assessed to operators of LLW disposal facilities.

To obtain a sense of how LLW management decisions are made and the factors that influence them, a survey was conducted of approximately $100 \mathrm{LLW}$ generators. The survey form (see Appendix) asked LLW generators to identify the type of industry they represent, to identify the LLW management options each has considered, to rank waste disposal decision factors according to their importance in their own operations, and to list conditions that complicate choices between LLW management alternatives.

\subsection{Organization}

Section 2 of this report gives the background behind the development of low-level waste compacts. Section 3 discusses the structures of disposal fees charged to waste generators.

Section 4 addresses the disposal options available to waste generators, and presents the results of the survey to better understand which options are most commonly used. Section 5 provides a summary and conclusions. 


\section{BACKGROUND}

\subsection{History and Status of Compact Development}

In the late 1970s, only three states, Washington, Nevada, and South Carolina, had operating commercial LLW disposal facilities sited within their borders. These states are called sited states. As political pressure mounted to limit the amounts of waste that the sited states disposed, they maintained that a more equitable arrangement was for the other states to accept responsibility for disposing of their own waste.

In response, legislation was introduced in Congress that made each state responsible for disposal of LLW generated within its borders. The legislation, known as the Low-Level Radioactive Waste Policy Act of 1980 (the Act), was passed by Congress and signed by the President. The Act allowed states to form compact regions that could restrict access to their disposal sites to only generators within their geographical regions.

Progress in developing new disposal facilities was slower than anticipated, and technical shortcomings were identified in the Act. Therefore, Congress passed the Low-Level Radioactive Waste Policy Amendments Act of 1985 (LLRWPAA). The LLRWPAA identified January 1, 1993, as the date by which the three sited states would be allowed to exclude waste from locations outside their compact regions.

By January 1, 1993, the Washington disposal facility had restricted its acceptance of LLW to states that are members of the Northwest Compact. Later, the Rocky Mountain Compact entered into a contract with the State of Washington and the Northwest Compact to allow waste from the Rocky Mountain Compact to be disposed of at the Washington facility.

Also, by January 1, 1993, the disposal facility in Nevada had closed and the South Carolina disposal facility began a policy of receiving LLW only from members of the Southeast Compact. Only waste from those states and compacts outside the Southeast Compact that had 18-month disposal contracts were allowed to continue disposing of their waste in South Carolina. Once the contracts expired on June 30,1994, only waste from the Southeast Compact was allowed. However, on July 1, 1995, South Carolina revised its waste acceptance policy and withdrew from the Southeast Compact. No longer encumbered by the restrictions of the compact, South Carolina opened its disposal facility to all generators throughout the United States except those in North Carolina. This determination was made because it was perceived that North Carolina, as the host State for the Southeast compact, had not made sufficient progress in siting a low-level waste disposal facility.

Currently, the Envirocare site at Clive, Utah, is available for certain types of LLW. When the facility opened in February 1988, it was licensed to receive only naturally occurring radioactive material (NORM). Through license amendments with the State of Utah, the Nuclear Regulatory Commission, and agreements with the Northwest Compact, Envirocare has expanded its waste acceptance capability to include 11 .e. 2 byproduct materials, mixed waste, and low actively/high volume LLW from all states.

Since passage of the original act and the subsequent amendments, Congress has approved nine interstate LLW compacts. Approval for one additional compact is pending. In these 
compacts, host states have been identified and disposal facility development activity has proceeded. Two states, California and Texas, have made the most progress in developing LLW disposal facilities (the proposed sites for these facilities are in Ward Valley and Sierra Blanca, respectively). California has issued a license for its facility, pending the transfer of the necessary land from the Federal Government. Texas is completing a review of the license application for its facility. As of October 1997, no new compact disposal facility has opened since passage of the Act in 1980 .

\subsection{Interviews}

Two series of interviews were conducted to obtain information for this report. The first with the management of the Barnwell, Richland, and Clive facilities, and the second with state agencies that regulate radiation safety at existing and proposed low-level waste disposal facilities State agencies interviewed included:

- California Department of Health Services

- South Carolina Department of Health and Environmental Control, Division of Radioactive Waste Management

- Texas Low-Level Radioactive Waste Disposal Authority

- Washington Department of Ecology, Low-Level Radioactive Waste Management Program. 


\section{DISPOSAL FEES}

This Section discusses the disposal fees charged by existing and proposed, future low-level waste disposal facilities. Section 3.1 provides a breakdown of the components included in the fees charged to waste generators. Section 3.2 then describes the fees and rates imposed by each facility for a hypothetical shipment of LLW.

\subsection{Disposal Fee Components}

The disposal fees charged by each LLW disposal facility recover the costs listed below plus a profit for the facility operator:

- Taxes-local and state/regional taxes charged to the facility.

- Mitigation/incentives-funds required for mitigation or compensatory measures for local impacts.

- Preoperational costs-siting, licensing/permitting, and facility construction.

- Operating expenses-labor, permitting fees, equipment maintenance, and monitoring.

- Closure and long-term care-funds required for facility closure and long-term maintenance and monitoring.

Preoperational and operating expenses are generally recovered by the "base rate" charged for disposal. However, taxes, mitigation/incentives, closure, and long-term care funds are usually collected as surcharges by the facility operator and distributed as appropriate.

The dollar amount of each of these fees varies from facility to facility. This is due to a variety of factors including its environmental setting, regulatory requirements, waste types and volumes, and disposal technologies employed at the site. For example, a shallow land burial facility located in an arid environment, receiving a large volume of waste requiring minimal handling, would have lower disposal fees than an engineered concrete vault facility in a humid environment that receives a small volume of waste.

Taxes, as well as the mitigation or incentive fees that are negotiated to allow each facility to operate, vary widely depending on local circumstances. Both the Barnwell and Richland commercial disposal facilities have historically paid city or county business or property taxes. As noted in Table 1, taxes range from $2.40 \%$ at the Barnwell facility to $3.45 \%$ at the Richland facility.

In addition to the county tax on the Barnwell facility, South Carolina collects a $\$ 235$ per cubic foot tax to support the state education fund. The Richland facility is assessed additional fees to cover state and Northwest Compact expenses related to the site. However, neither facility is required to pay any incentive or mitigation fees. By comparison, the proposed tax and fee structure for the Sierra Blanca, Texas, and Ward Valley, California, facilities will not include city or county taxes, but will include incentive or mitigation fees. These fees for the Sierra 
Blanca facility will be about $\$ 17.84$ per cubic foot and about $\$ 12.00$ for the Ward Valley facility.

Fees collected to pay for the closure and long-term care for each facility can be significant. Table 1 summarizes the closure and postclosure care funds that apply to the two operating (Barnwell and Richland) and the two proposed (Sierra Blanca and Ward Valley) commercial LLW disposal facilities. These fees are set by state regulatory agencies, and are based on their estimates of the total closure and post-closure costs and the amounts collected to date. The Barnwell and Richland facilities are collecting closure and long-term care fees at a rate of $\$ 15.40$ and $\$ 1.75$ per cubic foot, respectively.

The initial closure and postclosure care fees for new facilities such as the Sierra Blanca and Ward Valley facilities will likely be higher than what will be charged later in the life of each facility to accelerate the accumulation of funds in those accounts. The initial anticipated average closure and postclosure fees for the Sierra Blanca facility will be approximately $\$ 10$ per cubic foot and about $\$ 78$ per cubic foot for the Ward Valley facility.

Table 1. Taxes and fees applicable to active and proposed LLW disposal facilities.

\begin{tabular}{|c|c|c|c|c|}
\hline & $\begin{array}{l}\text { Chem-Nuclear, } \\
\text { Barnwell, } \\
\text { South Carolina }\end{array}$ & $\begin{array}{l}\text { US Ecology, } \\
\text { Richland, } \\
\text { Washington }\end{array}$ & 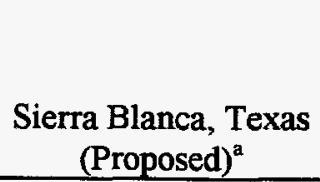 & $\begin{array}{l}\text { US Ecology, } \\
\text { Ward Valley, } \\
\text { California } \\
\text { (Proposed) }^{\mathrm{b}}\end{array}$ \\
\hline City/County Tax & $2.40 \%{ }^{\circ}$ & $3.45 \%{ }^{\mathrm{d}}$ & - & - \\
\hline Other Taxes and Fees & $\$ 235.00 / \mathrm{cf}^{\mathrm{e}}$ & $\$ 11.65 / \mathrm{cf}^{f}$ & None & $\$ 58.00 / \mathrm{cf}^{8}$ \\
\hline $\begin{array}{l}\text { Incentives and } \\
\text { Mitigation Costs }\end{array}$ & - & - & $\$ 17.84 / \mathrm{cf}$ & $\$ 12.00 / \mathrm{cf}^{\mathrm{h}}$ \\
\hline Closure Fund & $\$ 12.60 / \mathrm{cf}$ & - & $\$ 7.72 / \mathrm{cf}$ & $\$ 14.00 / \mathrm{cf}$ \\
\hline Post Closure Fund & $\$ 2.80 / \mathrm{cf}$ & $\$ 1.75 / \mathrm{cf}$ & $\$ 2.00 / \mathrm{cf}$ & $\$ 64.00 / \mathrm{cf}$ \\
\hline \multicolumn{5}{|c|}{$\begin{array}{l}\text { a. Current assumptions: } 1,800,000 \mathrm{cf} \text { total capacity, } 60,000 \mathrm{cf} \text { per year from Maine, Vermont, and Texas. } \\
\text { b. Current assumptions: } 75,000 \mathrm{cf} \text { per year capacity, } \$ 100,000,000 \text { preoperational costs, facility opening date } \\
\text { January, } 1999 \text {. }\end{array}$} \\
\hline \multicolumn{5}{|c|}{ c. Barnwell County tax on total of rates and charges. } \\
\hline \multicolumn{5}{|c|}{ d. Business and occupation tax on total of rates and charges (see footnote $\mathrm{c}$ in Table 2 for additional surcharges). } \\
\hline \multicolumn{5}{|c|}{$\begin{array}{l}\text { f. Benton County surcharge, } \$ 0.85 / \mathrm{cf} \text {; state surcharge, } \$ 6.50 / \mathrm{cf} \text {; site surveillance fee, } \$ 4.30 / \mathrm{cf} \text { (see Table } 2 \text { for } \\
\text { additional taxes and fees). }\end{array}$} \\
\hline \multicolumn{5}{|c|}{$\begin{array}{l}\text { g. Compact commission fees, } \$ 4 / \mathrm{cf} \text {; local government reimbursement, } \$ 27 / \mathrm{cf} \text {; Department of Health Services } \\
\text { regulatory fee, } \$ 27 / \mathrm{cf} \text {. }\end{array}$} \\
\hline \multicolumn{5}{|c|}{ h. Being considered by the California legislature in the "Needles Compensation Bill." } \\
\hline
\end{tabular}




\subsection{Fees for Hypothetical Shipment Disposal}

The disposal charges presented here are for a hypothetical commercial LLW shipment to the two operating disposal facilities, Barnwell and Richland, and to two proposed disposal facilities, Sierra Blanca and Ward Valley. The example demonstrates how the factors discussed in section 3.1 are applied and provides a comparison among the facilities. The data in this example illustrate the difficulty in arriving at conclusive comparisons between the facilities given the variations in location and local circumstances, disposal technologies, characteristics of waste received, state taxes, and specific surcharges. The information presented is not precise; however, facility operators found it to be in the range of what would be charged. The actual fees charged for disposal by Chem-Nuclear are confidential and negotiated between the generator and the disposal site operator. The actual fee for the two proposed facilities may change depending on when the facilities open.

The hypothetical shipment consists of one standard B-25 container with the following characteristics. It is assumed that all applicable waste acceptance criteria of the sites are met.

- Curie content-150 millicuries

- Burial volume--95.31 cubic feet

- $\quad$ Loaded weight- $-8,895$ pounds.

Table 2 shows that the estimated disposal fees for the sample shipment range from $\$ 613$ per cubic foot at Ward Valley to $\$ 111$ per cubic foot at Richland. The table shows that more than half of the disposal fee charged at Barnwell is attributable to the state's $\$ 235$ per cubic foot education tax. Excluding the education tax, the average disposal fee at Barnwell for the hypothetical shipment would be $\$ 183$ per cubic foot.

The data do not show that state Public Utility Commission (PUC) regulation guarantees low disposal costs. For example, the Ward Valley facility will be PUC-regulated, but the cost for disposing of this hypothetical shipment is high because the continuing delay to transfer the necessary land from the Bureau of Land Management to the state is resulting in ever increasing legal fees and interest expense. 
Table 2. Comparison of disposal costs for a hypothetical LLW shipment.

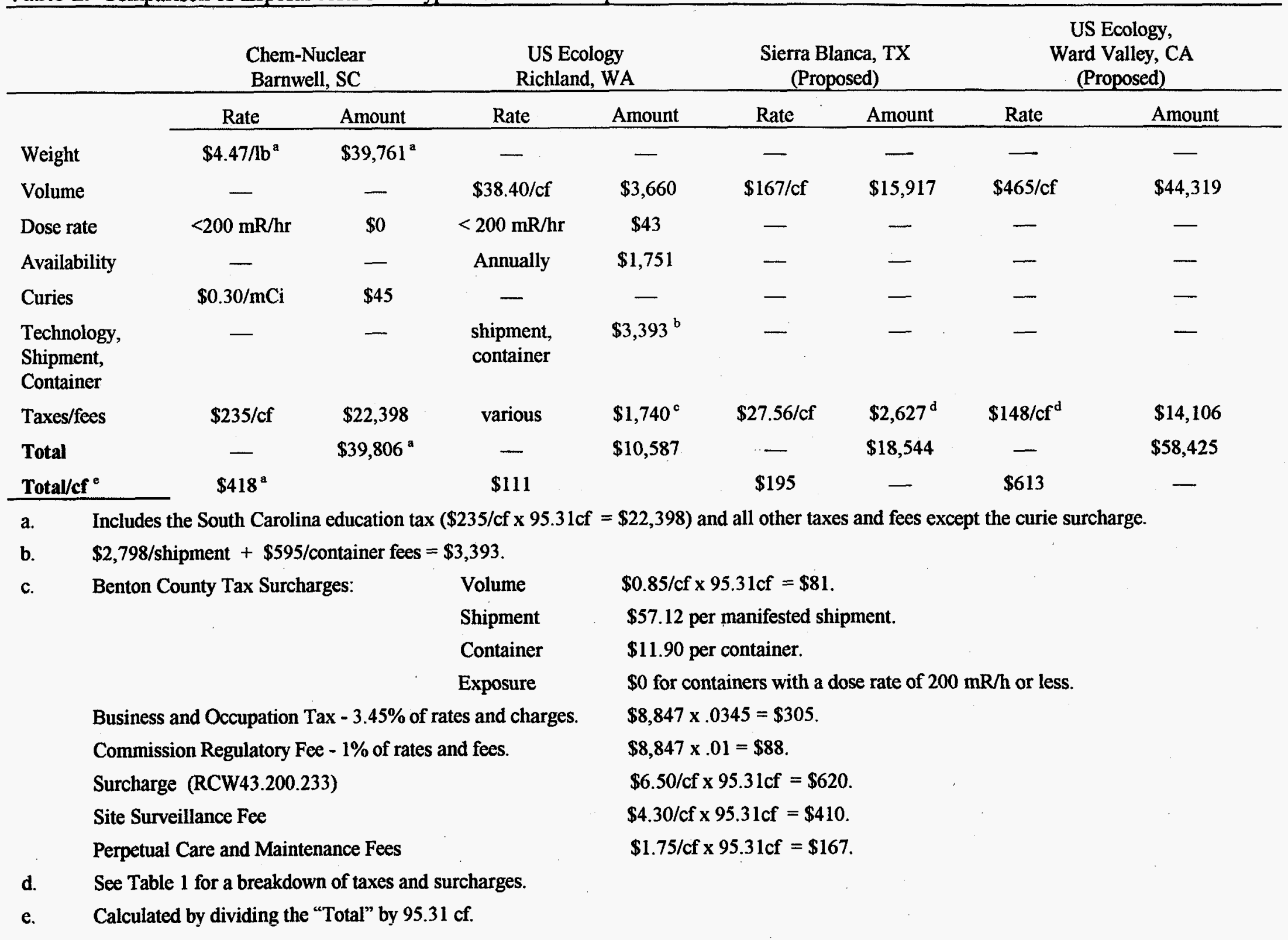




\section{WASTE MANAGEMENT OPTIONS}

Only three disposal facilities, South Carolina, Washington, and Utah, can receive the Nation's commercial LLW waste subject to the restrictions outlined in Table 3. South Carolina accepts waste from all states except North Carolina. States in the Northwest and Rocky Mountain compacts must send their waste to the Washington facility. The Utah site primarily accepts low activity wastes and certain mixed wastes from generators in all states.

Table 3. LLW disposal options currently available.

\begin{tabular}{lccc}
\hline \multicolumn{1}{c}{ Operator } & State & Permitted States & Acceptable Waste \\
\hline $\begin{array}{l}\text { Chem-Nuclear } \\
\text { Systems }\end{array}$ & $\begin{array}{c}\text { South } \\
\text { Carolina }\end{array}$ & All except North Carolina & $\begin{array}{c}\text { LLW } \\
\text { Low-activity }\end{array}$ \\
US Ecology & Washington & $\begin{array}{c}\text { Only Northwest Compact } \\
\text { and Rocky Mountain } \\
\text { Compact }^{b}\end{array}$ & $\begin{array}{c}\text { LLW } \\
\text { Low-activity }\end{array}$ \\
Envirocare & Utah & All & radioactive waste \\
& & & $\begin{array}{c}\text { Low-activity } \\
\text { radioactive waste }\end{array}$
\end{tabular}

a. North Carolina is excluded by South Carolina state law.

b. Northwest Compact policy restricts access to only the Northwest and Rocky Mountain compacts.

c. Low-activity, naturally occurring radioactive material (NORM) is accepted from all states.

Some generators opt to dispose of commercial LLW at current prices, while others choose to manage their waste in other ways. This diversity of waste management strategies among generators suggests that the basis for selecting a particular strategy depends upon the criteria used. To gain a sense of these issues, a survey was sent to $103 \mathrm{LLW}$ generators. Forty-one surveys were returned, for a response rate of $40 \%$. The number of surveys returned from each generator type is shown in Table 4. An underlying assumption of the survey was that generators would have continued access to the existing disposal facilities.

Table 4. LLW generator survey participants and rate of participation.

\begin{tabular}{lcc}
\hline \multicolumn{1}{c}{ Type of Generator } & Number of Surveys Returned & Percent of Total Returned \\
\hline Utility & 21 & $51 \%$ \\
Industry & 2 & $5 \%$ \\
Academic & 3 & $7 \%$ \\
Government & 6 & $15 \%$ \\
Medical & 9 & $22 \%$ \\
Total & 41 & $100 \%$ \\
\hline
\end{tabular}




\subsection{LLW Management Options}

Low-level waste generators have treatment, storage and disposal as waste management options available to them. Of the 41 generators that responded to the survey, Table 5 shows that most LLW generators choose to process their waste by incineration, waste minimization, and waste treatment in order to reduce the volume and weight. Other commonly used options include onsite temporary storage for decay $(63 \%)$ and onsite storage until other options are identified (49\%). Generators that chose the latter option explained that they are waiting for LLW management alternatives that would not only be less expensive but could also accept their specific types of waste. Of those surveyed, $93 \%$ have either considered using or are currently using Barnwell for commercial LLW disposal. Most generators explained that there are few options available, and that Barnwell is the only disposal site available to them. Because of compact restrictions, Hanford was selected as a LLW management option by only $27 \%$ of the generators. Over half $(54 \%)$ of the generators listed Clive as an alternative if their waste was within Clive's capability.

\subsection{Waste Management Decision Factors}

The third question in the LLW generator survey asked them to rate, on a scale from 1 to 5 ( 5 being most important), the decision factors that were used in arriving at the best waste management option. Generators identified four primary decision criteria for disposal of commercial LLW as follows (in decreasing order of importance):

- $\quad$ Disposal costs

- Waste acceptance criteria of the disposal facility

- Employee Safety

- Future Liability Concerns.

The decision factors and their relative importance from the survey responses are listed in Table 6. Each respondent could indicate more than one "most important" factor. A total of 31 generators $(76 \%)$ indicated that disposal costs is the most influential decision factor. The next most influential decision factor was waste acceptance criteria with 21 responses (51\%), followed by employee safety and future liability concerns. However, the public media tends to focus on other factors, e.g., storage space, transportation, local politics, etc. For generators, factors that directly affect the "bottom line" and the choice of disposal facilities appear to drive most LLW disposal decisions.

\subsection{Conditions that Complicate LLW Management Choices}

The final question of the survey asked LLW generators to describe conditions that complicate choices between LLW management alternatives. The respondents said that disposal costs and the lack of LLW disposal options are the primary complicating factors. 
Table 5. Summary of LLW management options considered by generators.

\begin{tabular}{ccc}
\hline & Positive & Percent of Total \\
LLW Management Option & Responses & Surveys Returned \\
\hline
\end{tabular}

Commercial Disposal

Barnwell

Hanford

Clive

\section{US DOE Disposal}

Los Alamos National Laboratory

Idaho National Engineering \&

Environmental Laboratory

Savannah River Site

Oak Ridge National Laboratory

Nevada Test Site

Interment Disposal

Onsite disposal facility

Offsite disposal facility

\section{Temporary Storage}

Onsite storage for decay

Onsite storage until other options are identified

Offsite storage for decay

Offsite storage until other options are identified

\section{Waste Processing}

Waste treatment

Incineration

Waste minimization 
Table 6. Most important decision factors for generators.

\begin{tabular}{lcc}
\hline \multicolumn{1}{c}{$\begin{array}{c}\text { Most Important } \\
\text { Decision Factor }\end{array}$} & $\begin{array}{c}\text { Positive } \\
\text { Responses * }\end{array}$ & $\begin{array}{c}\text { Percent of } \\
\text { Total Surveys Returned }\end{array}$ \\
\hline Disposal Costs & 31 & $76 \%$ \\
Waste Acceptance Criteria & 21 & $51 \%$ \\
Employee Safety & 18 & $44 \%$ \\
Future Liability Concerns & 17 & $41 \%$ \\
Waste Preparation Costs & 13 & $32 \%$ \\
Storage Space Availability & 12 & $29 \%$ \\
Public Relations & 10 & $24 \%$ \\
Transportation Costs & 9 & $22 \%$ \\
Timeliness & 7 & $17 \%$ \\
Transportation Regulations & 6 & $15 \%$ \\
Politics & 5 & $12 \%$ \\
Internal Guidance Document & 4 & \\
\hline Several generators listed more than one factor as “most important." & \\
\hline & $5 \%$ & \\
\hline
\end{tabular}




\section{SUMMARY}

At the request of Congress, DOE performed this study to examine the operating costs for commercial LLW disposal facilities to determine if waste generators are paying equitable disposal fees. Comparative data in this report indicate that operating costs vary significantly between facilities due to climate, disposal technology, waste characteristics, and other factors. Disposal fees charged to generators are based on the costs of operating a disposal facility, i.e., higher operating costs result in higher disposal fees; they are not based on the size, location, or type of generator using a given facility. Generators identified current disposal costs as their primary concern. This concern may only escalate as future disposal costs are likely to be higher. 


\section{APPENDIX}

LOW-LEVEL WASTE DISPOSAL EVALUATION QUESTIONNAIRE 


\section{LOW-LEVEL WASTE DISPOSAL EVALUATION QUESTIONNAIRE}

1. Type of waste generator.

a) $\square 01$. Utility

प02. Industry

D03. Academic

D04. Government

$\square 05$. Medical

b) $\square$ 06. Public

口07. Private

2. What are the LLW management options you have considered? Select all options that apply, underline the option you are currently using. Please explain why each option has (has not) been considered.

a) Commercial Disposal

प08. Bamwell

$\square 09$. Hanford

$\square$ 10. Envirocare

$\square$ 11. Other (please specify)

b) USDOE Disposal

प12. LANL

[13. INEEL

$\square$ 14. Savannah River

口15. Oak Ridge

口16. Nevada Test Site

$\square 17$. Other (please specify)

c) Interment Disposal

$\square$ 18. On-site Disposal Facility

$\square$ 19. Off-site Disposal Facility (location) _

口20. Other (please specify) d) Temporary Storage

$\square$ 21. On-sile Storage for Decay

$\square 22$. On-site Temp. storage until other options identified.

$\square$ 23. Other On-site (please specify)

$\square$ 24. Off-site storage for decay

$\square$ 25. Off-site temp. storage until other cptions identified.

$\square 26$. Other off-site (please specify)

e) Waste Processing

$\square 27$. Wasle Treatment (specify)

Q28. Incineration

$\square$ 29. Waste Minimization (Recycle \& Reuse)

$\square$ 30. Administrative Controls (BMPs)

$\square$ 31. Other (please specify) 
LOW-LEVEL WASTE DISPOSAL EVALUATION QUESTIONNAIRE (continued)

3. What are the decision factors used in arriving at the best waste management option chosen above?

$$
\begin{array}{ccccl}
\text { No influence....... Most influence } \\
\square & \square & \square & \square & \square \text { Internal Guidance Document } \\
\square & \square & \square & \square & \square \text { Transportation Regulations } \\
\square & \square & \square & \square & \square \text { Waste Acceptence Criteria of } \\
\square & \square & \square & \square & \square \text { Storage Space Avaidability } \\
\square & \square & \square & \square & \square \text { Future Liability Concerns } \\
\square & \square & \square & \square & \square \\
\square & \square & \square & \square & \square \text { Preparation Costs } \\
\square & \square & \square & \square & \square \text { Transportation Costs } \\
\square & \square & \square & \square & \square \text { Disposal Costs } \\
\square & \square & \square & \square & \square \text { Employee Safety } \\
\square & \square & \square & \square & \square \text { Public Relations } \\
\square & \square & \square & \square & \square \text { Timeliness } \\
\square & \square & \square & \square & \square \text { Politics }
\end{array}
$$

Please provide any explanation

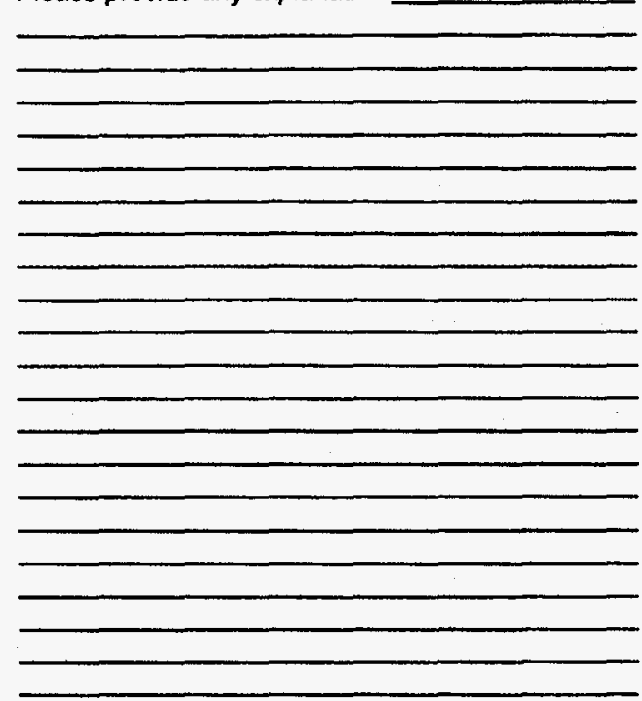

4. Please describe the conditions that complicate choices of LLW management altematives.

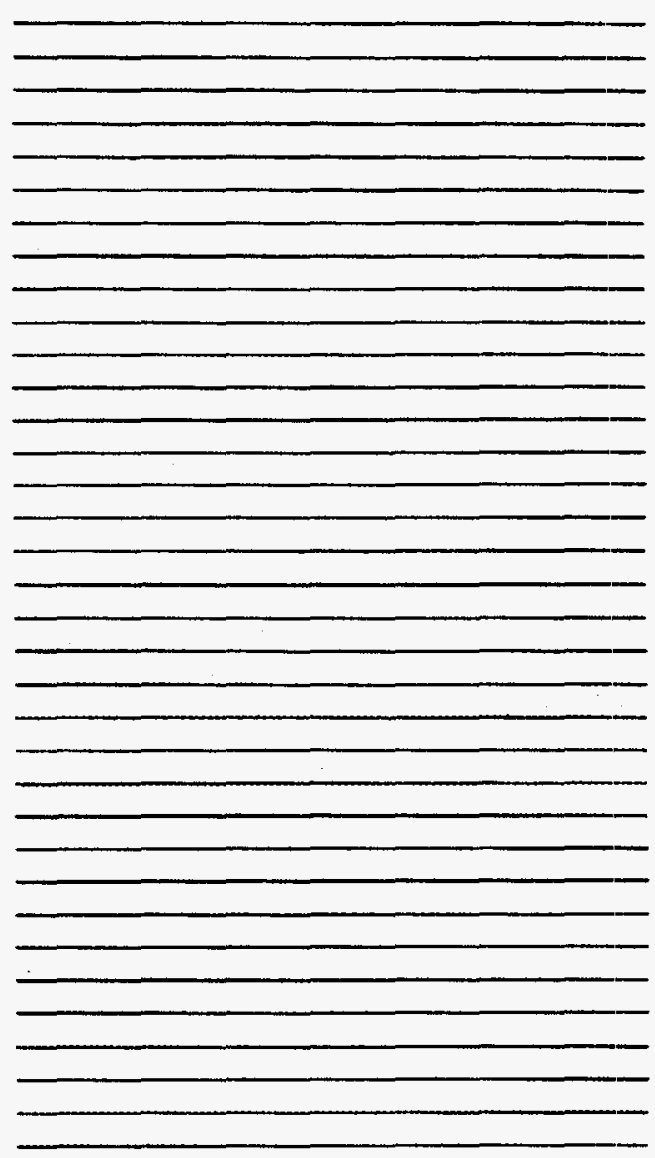

